\title{
Field Efficacy of Different IPM Modules for Management of Aphid on Cumin (Cuminum Cyminum L.) Under Semi-Arid Conditions
}

\author{
Narottam Kumar Meena ( $\nabla$ narottammeena@gmail.com ) \\ ICAR-National Research Centre on Seed Spices \\ Ram Swaroop Meena \\ ICAR-National Research Centre on Seed Spices \\ Ravindra Singh \\ ICAR-National Research Centre on Seed Spices \\ Murlidhar Meena \\ ICAR-National Research Centre on Seed Spices \\ Arvind Kumar Verma \\ ICAR-National Research Centre on Seed Spices \\ Sharda Choudhary \\ ICAR-National Research Centre on Seed Spices \\ Y Ravi \\ ICAR-National Research Centre on Seed Spices \\ Shailendra Nath Saxena \\ ICAR-National Research Centre on Seed Spices
}

\section{Research Article}

Keywords: IPM modules, Cuminum cyminum, Aphid, Economics, Field validation

Posted Date: December 20th, 2021

DOI: https://doi.org/10.21203/rs.3.rs-1182026/v1

License: @ (i) This work is licensed under a Creative Commons Attribution 4.0 International License. Read Full License 


\section{Abstract}

Aphid, Myzus persicae (Sulzer) and Aphis gossypii Glower (Hemiptera: Aphididae) are the two major species damaging cumin crop throughout the cumin growing states of India. Its infestation initiated on cumin crops at 20 days after seed germination with very low incidence and became abundant at 70-80 day after seed germination during second week of January till February when crops are in full grown stage. Since cumin is most important seed spice crop, having huge nutritional, medicinal and aromatic properties, and its seed and essential oil is exporting in many countries over the world, hence quality production is the major challenge for the growers. The multiple sprays of chemical pesticides with heavy doses for pest management induce resistance in aphids, harmful to natural enemies and also enhance the pesticide residue level in the produce (seed). With this approach, the present study was conducted for two consecutive years to evaluate the cumulative effect of botanicals, cultural and physical methods, bio-pesticides, and bio-control agents and insecticides in the form of IPM module for the management of aphid and relative safety to natural enemies in cumin under field conditions. In this study, amongst eight different IPM modules evaluated against aphid, module M-5 consisted by seed treatment with imidacloprid 600FS @ 3ml/kg seed followed by foliar spray of ker plant extract @ 10ml/litre, Verticillium lecanii $\left(1 \times 10^{8} \mathrm{cfu} / \mathrm{g}\right) @ 6 \mathrm{~g} /$ litre, and fipronil 5\%SC @ 0.035\% at definite interval secured efficient management of aphids ( $>92 \%$ mortality) with relative safety to natural enemies and minimized pesticide residue in the seeds. The highest seed yield (934 kg/ha), test weight (5.24 g), essential oil (5.98\%), economics (Rs.1.08 Lakh) and B: C ratio (3.69:1) was obtained by the application of IPM modules M-5. Similarly, the higher seed yield $1072.5 \mathrm{~kg}$ per hectare $(21.19 \%$ appreciation over farmers practices) was also recorded in field validation study under non replicated field in large area, proved its effectiveness by the farmers. Consequently, it recommends that IPM module M-5 consisted with botanical product, entomopathogenic fungi and insecticides exhibited sustainable aphid management module for cumin, comparatively safer to natural enemies and lower residue level in the seeds.

\section{Introduction}

Aphid species Myzus persicae (Sulzer) and Aphis gossypii Glover (Hemiptera: Aphididae) are the major pest problem of cumin in India ${ }^{1,2}$. These species are geographically distributed throughout the world, considered as cosmopolitan in habitat $^{3}$. Both species are reported to be a polyphagous pest, as they feed on more than 400 plants species of 40 plant families including many economically important crops $^{4,5}$. They are the phloem sap-feeding pests, feeding on various crops $^{6}$ cause severe yield loss in okra, cotton, eggplant ${ }^{5,7-10}$, field and horticultural crops and several weed plants year round.

Cumin (Cuminum cyminum L.; Family: Apiaceae) known as 'Zeera' in Hindi is an important seed spice. It is a native of the Levant and Upper Egypt and now it is grown mainly in hot countries, especially India, Pakistan, Iraq, Iran, Turkey, China, Syria, Israel and Italy ${ }^{1}$. India is one of the largest producer, consumer and exporter of cumin seed as it grown in 12.76 lakh hectare area produced 9.12 lakh tonnes seed during 2019-2011 and also exported 2.14 lakh tonnes cumin seed, valued for 3328 crore $^{12}$ play a vital role in Indian's agricultural economy. In India, cumin is exclusively cultivated in Rajasthan and Gujarat and both the states together contribute more than $95 \%$ of total country's cumin production. It is widely used as spice for flavouring in various food preparations. The flavour of cumin seeds is due to the presence of volatile oil. The cumin seeds contain $2-5 \%$ volatile oil with $60 \%$ cuminaldehyde; $22 \%$ fats, amino acids, flavonoids and glycosides, and the yellow coloured fresh oil contains cuminaldehyde as its chief component ${ }^{13,14}$. Cumin seeds also have huge nutritional value viz., $17.7 \%$ protein, $35.5 \%$ carbohydrate and $7.7 \%$ minerals. Cumin seeds are also having several medicinal properties used as stimulant, antioxidant ${ }^{15}$, antidiabetic ${ }^{16}$, antiseptic, antihypertensive herb ${ }^{17,18}$, cholesterol level reducer ${ }^{19}$, carminative, stomachic, astringent and constructive in diarrhea and dyspepsia ${ }^{20}$. Cuminaldehyde is good detoxicant which help in the regular removal of toxins from the body. 
Cumin crop is infested with several insect-pests, and among them, aphid is the major pest problem, causes more than $50 \%$ yield loss 21,22 and it can be extended up to $80 \%$ in absence of proper and timely control. M. persicae complete their life cycle quickly, takes 10 to 16 days on cumin ${ }^{23}$ and 10 to 12 days on Eruca sativa ${ }^{24}$ under favourable conditions. The rapid multiplication of aphid makes this pest more dangerous for crop plants. Aphid infestation emerges on cumin in mid December when crops are in seedling stage and continued up to crop's seed formation stage. Severe infestations of aphid were reported in the month of January- February ${ }^{25,26}$, when crop attains flowering to seed formation stages and farmers apply 4 to 5 sprays of chemical pesticides with heavy doses. Multiple sprays of insecticides may lead to the quick development of resistance ${ }^{27-30}$, mortality of natural enemies ${ }^{31-33}$ and harvested cumin seeds retained heavy pesticide residue. Such cumin produce is unfeasible for human health as well as unsuitable for export in developed countries. Since, cumin is being a potential seed spice crop of the country; indiscriminate use chemical pesticides induces resistance in aphids against number of insecticides, kill natural enemies and create pesticide residue in seeds with low yield and quality. Keeping above aims in view, the present study was carried to develop a suitable IPM module using cultural, botanicals, biocontrol agents, mechanical means and judicial chemical insecticides in a compatible manner in the form of eco-friendly pest management approach to sustainably manage the aphids which minimize the use of chemical pesticides, residue level in seed and save the natural enemies. Such IPM modules improve the human and environmental health, and also enhance the productivity of quality cumin seeds.

\section{Materials And Methods}

\section{Study area.}

The field investigations were carried out at the Research Farm of ICAR-National Research Centre on Seed Spices, Ajmer (Rajasthan), India during winter season for two successive years 2018-19 and 2019-20. The experimental site is surrounded by Aravalli hill range which is lying between $74^{0} 35^{\prime} 39^{\prime \prime}$ to $74^{0} 36^{\prime} 01^{\prime \prime}$ E longitude and $26^{0} 22^{\prime} 12^{\prime \prime}$ to $26^{\circ} 22^{\prime}$ 31 " $\mathrm{N}$ latitude at an altitude of $486 \mathrm{~m}$ above mean see level ${ }^{34}$. The study area is considered as semi-arid region of the country, where summers are extreme hot and winters are cold; where the mean daily temperature ranged between 37 to $48^{\circ}$ Celsius in May-June and 6 to $12^{\circ}$ Celsius in January-February. The area receives annual average rainfall of 300-550 $\mathrm{mm}$, whereas, the relative humidity was ranged from $60-80 \%{ }^{1}$ and medium low to medium fog was observed during study period.

\section{Experimental detail.}

The experimental trials were conducted for two consecutive years to find out the efficiency of eight different IPM modules for the sustainable management of aphid's mixed population in cumin under open field conditions. Field experiments were laid out in randomized block design with three replications. The seeds of cumin variety GC-4 were sown in well prepared field, splitted in plots sized of $5 \times 4$ meters under specified crop geometry $(30 \times 20 \mathrm{~cm}$ row to row and plant to plant spacing) and followed all recommended good agricultural practices (GAP) of cumin were adapted to the crop for luxurious growth and quality production. Eight different IPM modules consisted with cultural practices (uprooting weedsan alternate host of aphid), botanicals (manually prepared locally available wild plant formulations and marketed products), bio-control agents, mechanical (yellow sticky traps) and chemical insecticides were strategically arranged in a compatible manner and evaluated against aphids under four application schedules at different intervals. The details of treatment combinations i.e. product name, dose/conc. and methods of application are given in Table 1A. In application schedule, first treatment of each IPM module was applied as seed treatment as well as soil application at the time of seed sowing; second treatment at 45 days after germination and third treatment was applied at 70 days after germination when sufficient aphid population was reported, whereas, last fourth application was applied at 85 days after germination. 
Entomologically potential two uncultivable plants viz., ker [Capparis decidua (Forssk.) Edgew] and tumba [Citrullus colocynthis (L.) Schrad.], which are available plenty in arid and semi-arid regions of India were taken into the study. To prepare aqueous extract, one year old shoots and stems of ker plants contain capparisinine a potential active chemical compound $\mathrm{LD}_{50} 2.0 \mu \mathrm{g} / \mathrm{g}^{35,36}$ were collected in winter season (December-January) from nearby field to experimental location and brought into the laboratory. Plant shoots and stems were chopped into small pieces and then washed thoroughly with running water in order to get rid of dirt, insects and planktons. Plant sap of collected material was extracted through juice extracting machine by adding $200 \mathrm{ml}$ distilled water in $1 \mathrm{~kg}$ ker foliage as per methodology developed by Meena et al. ${ }^{37}$. Similarly, the fruits of $C$. colocynthis contain insecticidal properties due to colocynthin ${ }^{38}$ and cucurbitacin E glycosides compounds ${ }^{39-42}$. In this study, fresh ripen tumba fruits having potential active chemical compound $\mathrm{LC}_{50} 6.26 \mathrm{mg} / \mathrm{mL}^{43}$ were collected from Jaisalmer in western Rajasthan (Coordinates: $26.9127^{\circ} \mathrm{N}, 70.9122^{\circ} \mathrm{E}$ ) during October and brought into the laboratory. To obtained extract solution, fruits were washed with running water and then pulp along with seeds was separated with the help of stainless steel knife. $1 \mathrm{~kg}$ fruit pulps mixed with $300 \mathrm{ml}$ distilled water and ground in electric mixture-grinder to obtained fruit extract and then extract was filtered through muslin cloth. Spray solution of these botanicals were prepared by dissolving standardized doses $10 \mathrm{ml}$ of each extract in one litre of water and also added sticker @ $1 \mathrm{ml} /$ litre of water for spraying on the crop against aphid. Neem seed kernel extract (NSKE) was also prepared manually by the use of neem seeds of 10-15 years old trees, collected from own experimental farm during May-June and dried in shade. To obtained NSKE, gently grind $1 \mathrm{~kg}$ dried neem seed kernels, contains $0.2-0.3 \%$ azadirachtin (potential active chemical compound) ${ }^{44}$ to powder it and soaked in 2 litre good quality water overnight and then stir with wooden plank in the morning till solution becomes milky white and filtered the extract with doubled layer muslin and made the volume to 10 liter and also added $20 \mathrm{~g}$ detergent while spraying on the crop. Neem and castor cakes were applied as treatment of soil application @ 500 and $300 \mathrm{~kg} /$ hectare, respectively at the time of sowing. Local population of Coccinella septempunctata larvae @ 500/acre were released on cumin plants. Entomopathogens Verticillium lecanii, Beauveria bassiana and Metarhizium anisopliae and a fungal antagonist Trichoderma viride were taken from the ICAR-National Bureau of Agricultural Insect Resources, Bengaluru, India, while remaining chemicals and materials were procured from reputed firms in the market and the detailed information is given in Table 1B. Imidacloprid 600 FS (Gaucho) is a systemic insecticide, thus it applied as seed treatment at lower dose (3ml/kg seed) to protect crop from aphid for initial 40-45 days and minimize residue in seeds. Fipronil 5\% SC (Regent) is highly effective against sucking pests in low dose with short waiting period (6-7 days) and also not banned for use in many Asian countries including India, thus it included in the experiment. It applied as foliar application at 85 days after germination during crop's full grown vegetative growth stage, does not harm the pollinators and reduce the residue level in seeds.

The visual observations of aphid population were recorded right from 10 days after germination to 60 days after germination at 10 days interval by counting of number of aphid (nymphs and adults) on randomly selected 5 plants per plot in all replications. Initially, the whole plant was taken into account for observations but in later growth stage, three branches/ plant, and then three umbels/plant at flowering were taken. Similarly, a visual observation of number of aphids both nymph and adults per plant for 5 plants/plot was recorded 1 day before third and fourth applications of treatments, considered as pre treatment count (PTC) and the post treatment observations were recorded by counting of number of live aphids at 1, 3, 7 and 10 days after each spray application. Effectiveness of IPM modules was measured in term of per unit area yield appreciation over control. IPM module-wise, marketable seed yield was recorded from each plot harvested separately. The most effective and deliverable IPM module M-5 along with standardized GAP was also evaluated at farmer's field to compare with farmer's local pest management practices for validation of yield data at farmer's level. Based on two years pooled yield, economics of IPM modules was also worked out to find their benefit cost effectiveness for cumin growers. The quality of cumin seed was also assessed in terms of test weight and essential oil contents. For this, weight of 1000 clean seeds was measured using physical balance and essential oil was extracted from $30 \mathrm{~g}$ dried cumin seed powder using hydro-distillation method ${ }^{45}$. 


\section{Data analysis.}

The data collected was subjected to statistical analysis by calculating analysis of variance (ANOVA) as randomized block design after suitable transformations. The percent mortality of aphids in each treatment was calculated and corrected by Abbott's formula ${ }^{46}$ as follows:

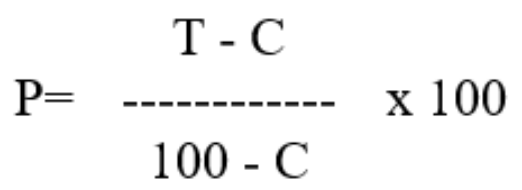

Where, $\mathrm{P}=$ Corrected per cent mortality; $\mathrm{T}$ = Observed per cent mortality in treatment; $\mathrm{C}=$ Percent mortality in control.

The corrected per cent mortality thus obtained were analyzed after converted into arc sin values and tabulated to statistically analysis; after the analysis, the original units were converted to determine the various treatment effects. IPM module-wise marketable seed yield of each year was recorded, and converted in to seed yield kg per ha. The mean separation of number of aphids till 60 days after germination and per cent mortality in aphids in last two applications and seed yield was performed using Duncan's Multiple Range test DMRT $(P \leq 0.05)$. The statistical analysis was done using the SPSS statistical software.

\section{Results}

\section{Field efficacy of IPM modules.}

In first year result, all IPM module significantly reduced the aphid population ( $P \leq 0.05$, Duncan's Multiple Range test DMRT) in all replications compared to control at 10,20,30,40, 50 and 60 days after germination in first and second application (Table 2). The first application was done at the time of sowing as seed and soil treatment, wherein 10 days after germination, the means of aphid population per plant were ranged from 0.2 to 0.8 aphids in the treatments of $M-4$ and $M-6$, but statistically differed to control, whereas, remaining treatments were free from aphid infestation. At 20, 30 and 40 days after germination, there was an increase in infestation of aphid in all the treatments $(P \leq 0.05)$, but significantly less than the control. At 40 days after germination in first application, no aphid infestation was recorded in IPM module M5 and M-7 included seed treatment with imidacloprid 600 FS and thiamethoxam 25 WG, respectively. Similarly, the IPM modules M-3, M-2, M-4 and M-6 with soil treatments of caster cake, neem cake and seed treatments of neem oil and Trichoderma viride were rated as next effective modules recorded 1.0, 1.2, 1.2 and 1.6 aphids/plant, respectively and were statistically on par with each other. IPM module M-1 with cultural treatment (2.2 aphids/plant) recorded less effective among treatments against aphid on cumin. 
Table 1

A. Details of IPM modules applied for the management of aphids on cumin in 2018-19 and 2019-20; Note: Two local uncultivable plants: Ker plant is botanically known as Capparis decidua (Forssk.) Edgew., and tumba plant (Citrullus colocynthis Lin.), SA- soil application, ST- seed treatment

\begin{tabular}{|c|c|c|c|c|}
\hline \multirow{3}{*}{$\begin{array}{l}\text { IPM } \\
\text { Module }\end{array}$} & \multicolumn{4}{|c|}{ Treatment combinations of IPM modules } \\
\hline & 1st Application & 2nd Application & 3rd Application & 4th Application \\
\hline & (At sowing time) & (45 days after germination) & $\begin{array}{l}\text { (70 days after } \\
\text { germination) }\end{array}$ & $\begin{array}{l}\text { (85 days after } \\
\text { germinations) }\end{array}$ \\
\hline$M-1$ & $\begin{array}{l}\text { Cultural method (uprooting } \\
\text { alternate host plants) }\end{array}$ & $\begin{array}{l}\text { Yellow sticky trap @25 } \\
\text { traps/acre }\end{array}$ & $\begin{array}{l}\text { Ker plant extract @ } \\
10 \mathrm{ml} / \text { lit. }\end{array}$ & $\begin{array}{l}\text { Acetamiprid } \\
20 \% S P @ 0.025 \%\end{array}$ \\
\hline M-2 & $\begin{array}{l}\text { Neem cake (Soil application } \\
@ 500 \mathrm{~kg} / \mathrm{ha} \text { ) }\end{array}$ & $\begin{array}{l}\text { Cultural method (uprooting } \\
\text { alternate host plants) }\end{array}$ & NSKE (5\%) & $\begin{array}{l}\text { Fipronil 5\%SC @ } \\
0.035 \%\end{array}$ \\
\hline M-3 & $\begin{array}{l}\text { Castor cake @ 300kg/ha } \\
\text { (SA) }\end{array}$ & $\begin{array}{l}\text { Azadirachtin } 0.03 \text { EC @ } \\
\text { 3ml/lit. }\end{array}$ & $\begin{array}{l}\text { Tumba fruit extract @ } \\
10 \text { ml/lit. }\end{array}$ & $\begin{array}{l}\text { Thiacloprid } 240 \\
\text { SC @0.025\% }\end{array}$ \\
\hline M-4 & Neem oil 3\% @ 5 ml/lit. (ST) & Yellow sticky trap 25/Acre & $\begin{array}{l}\text { Coccinella larvae } \\
\text { @5000/acre }\end{array}$ & $\begin{array}{l}\text { Imidacloprid } 17.8 \\
\text { SL @ 0.003\% }\end{array}$ \\
\hline M-5 & $\begin{array}{l}\text { Imidacloprid 600FS @ } \\
3 \mathrm{ml} / \mathrm{kg} \text { seed (ST) }\end{array}$ & Ker plant extract @ 10ml/lit. & $\begin{array}{l}\text { Verticillium lecanii } \\
\left(1 \times 10^{8} \mathrm{cfu} / \mathrm{g}\right) @ 6 \mathrm{~g} / \mathrm{lit} .\end{array}$ & $\begin{array}{l}\text { Fipronil 5\%SC @ } \\
0.035 \%\end{array}$ \\
\hline M-6 & $\begin{array}{l}\text { Trichoderma viride@6g/kg } \\
\text { seed (ST) }\end{array}$ & $\begin{array}{l}\text { Coccinella larvae @ } \\
\text { 5000/acre }\end{array}$ & $\begin{array}{l}\text { Beauveria bassiana@ } \\
6 \mathrm{~g} / \text { lit. }\end{array}$ & $\begin{array}{l}\text { Fipronil 5\%SC @ } \\
0.035 \%\end{array}$ \\
\hline$M-7$ & $\begin{array}{l}\text { Thiamethoxam } 25 \text { WG @ } \\
5 \mathrm{~g} / \mathrm{kg} \text { seed (ST) }\end{array}$ & $\begin{array}{l}\text { Azadirachtin 0.03EC @ } \\
5 \mathrm{ml} / \text { lit. }\end{array}$ & $\begin{array}{l}\text { Metarhizium } \\
\text { anisopliae@6g/lit }\end{array}$ & $\begin{array}{l}\text { Acetamiprid } 20 \\
\text { SP @0.025\% }\end{array}$ \\
\hline M-8 & Untreated control & Untreated control & Untreated control & Untreated control \\
\hline
\end{tabular}


Table 2

Field efficacy of first \& second applications of different IPM modules against aphid on cumin in rabi 2018-19 \& 2019-20; Note: Value given in table is the mean of 15 plants from three replications; DAG-days after germination; In column, means followed by common letters are not significantly different at $(\mathrm{P} \leq 0.05)$ by Duncan's Multiple Range test (DMRT).

\begin{tabular}{|c|c|c|c|c|c|c|}
\hline \multirow[t]{4}{*}{ IPM module } & \multicolumn{6}{|c|}{ Aphid population (No. of aphid/plant up to 40 DAG and per branch till 60 DAG) } \\
\hline & \multicolumn{3}{|c|}{ 1st Application } & & \multicolumn{2}{|c|}{ II ${ }^{\text {nd }}$ Application } \\
\hline & \multicolumn{6}{|l|}{ 2018-19 } \\
\hline & $10 \mathrm{DAG}$ & 20 DAG & 30 DAG & 40 DAG & 50 DAG & 60 DAG \\
\hline M-1 & $0^{c}$ & $0.2^{\mathrm{c}}$ & $1^{\mathrm{b}}$ & $2.2^{\mathrm{b}}$ & $4.6^{b}$ & $5^{\mathrm{bc}}$ \\
\hline M-2 & $0^{c}$ & $0^{d}$ & $1.4^{b}$ & $1.2^{\mathrm{C}}$ & $5^{b}$ & $5.2^{\mathrm{b}}$ \\
\hline M-3 & $0^{\mathrm{c}}$ & $0.2^{\mathrm{c}}$ & $0.4^{\mathrm{c}}$ & $1^{\mathrm{c}}$ & $2.2^{d}$ & $2.4^{\mathrm{e}}$ \\
\hline M-4 & $0.2^{\mathrm{b}}$ & $0.4^{\mathrm{b}}$ & $1.2^{b}$ & $1.2^{\mathrm{c}}$ & $3^{c}$ & $3.8^{\mathrm{cd}}$ \\
\hline M-5 & $0^{c}$ & $0^{d}$ & $0^{c}$ & $0^{d}$ & $0^{e}$ & $0.4^{f}$ \\
\hline M-6 & $0.2^{b}$ & $0.2^{c}$ & $1^{b}$ & $1.6^{\mathrm{bc}}$ & $1.8^{d}$ & $3^{\text {de }}$ \\
\hline M-7 & $0^{c}$ & $0^{d}$ & $0^{c}$ & $0^{d}$ & $0.2^{\mathrm{e}}$ & $1^{f}$ \\
\hline \multirow[t]{2}{*}{$M-8$} & $0.8^{a}$ & $1^{a}$ & $3.2^{\mathrm{a}}$ & $4^{a}$ & $7.6^{\mathrm{a}}$ & $11.4^{\mathrm{a}}$ \\
\hline & \multicolumn{6}{|l|}{ 2019-20 } \\
\hline M-1 & $0.2^{a b}$ & $1^{a}$ & $1.4^{b}$ & $4.4^{\mathrm{b}}$ & $4^{\mathrm{bc}}$ & $8.2^{\mathrm{b}}$ \\
\hline M-2 & $0.2^{a b}$ & $0.4^{\mathrm{bc}}$ & $1^{\mathrm{c}}$ & $3.6^{b c}$ & $3.2^{\mathrm{bc}}$ & $7.4^{\mathrm{b}}$ \\
\hline M-3 & $0^{b}$ & $0.4^{b c}$ & $0.6^{d}$ & $2^{d}$ & $1.4^{\mathrm{d}}$ & $2^{d}$ \\
\hline M-4 & $0^{b}$ & $0^{c}$ & $1.2^{\mathrm{bc}}$ & $4^{\mathrm{bc}}$ & $4.4^{b}$ & $5^{c}$ \\
\hline M-5 & $0^{\mathrm{b}}$ & $0^{c}$ & $0^{e}$ & $0^{e}$ & $0.2^{d}$ & $1.2^{\mathrm{d}}$ \\
\hline M-6 & $0.4^{a b}$ & $0.6^{a b}$ & $1.2^{b c}$ & $3^{c d}$ & $3^{c}$ & $3.8^{c}$ \\
\hline M-7 & $0^{\mathrm{b}}$ & $0^{c}$ & $0^{e}$ & $0.2^{\mathrm{e}}$ & $0.4^{d}$ & $1.6^{\mathrm{d}}$ \\
\hline M-8 & $0.6^{a}$ & $1^{\mathrm{a}}$ & $2.2^{\mathrm{a}}$ & $6.2^{\mathrm{a}}$ & $10.6^{a}$ & $14^{\mathrm{a}}$ \\
\hline
\end{tabular}

In second application, made on 45 days after germination and aphid population was recorded at 50 and 60 days after germination, showed that there was an increase in infestation of aphid in all the treatments except M-5 (P $\leq 0.05)$, but significantly less than to control. At 50 days after germination, no aphid was recorded in IPM module M-5, whereas, the lowest mean aphid population was recorded with IPM module M-7 (0.2 aphids/plant) but statistically on par with M-5. The next effective IPM modules were M-6 (1.8 aphids/plant), M-3 (2.2 aphids/plant) and M-4 (3.0 aphids/plant) followed by M1 (5 aphids/plant) and M-2 (4.6 aphids/plant). IPM module M-1 was recorded least effective module at this stage in management of aphids on cumin. A similar trend was evident after 60 days of germination in second application, wherein 
lowest infestation was recorded in IPM module M-5 (0.4 aphids/plant) than M-7 (1.0 aphid/plant) and both were statistically on par to each other (Table 2).

Per cent mortality in aphid population in third and fourth applications of IPM modules due to treatments (Table 3) showed that all treatments significantly reduced the aphid populations ( $P \leq 0.05$, Duncan Multiple Range Test) in all replications as compared to control at 1, 3, 7, and 10 days after treatments. There was a significant increase in per cent mortality of aphid recorded till 7 days after third application, and then decreased at 10 days after treatment. At 7 days after treatment, aphid populations were reduced in all treatment applications in comparison with the control. The highest mortality (81.80\%) in aphid population was recorded with IPM module M-5 (Verticillium lecanii) followed by M-7 (Metarhizium anisopliae) reduced 78.91 per cent aphid population and both modules were statistically on par. The next effective IPM modules were M-3 (tumba fruit extract), M-6 (Beauveria bassiana) and M-4 (Coccinellid larvae) reduced 71.61, 70.50 and 69.35 per cent aphid population, respectively. IPM module M-1 was recorded as least effective module in management of aphids on cumin. A similar trend of mortality in aphid population was recorded in fourth application, where all IPM modules were found significantly superior in management of aphid over control (Table 3). At 7 days after treatment, the highest mortality (92.32\%) in aphid population was recorded with IPM module M-5 (fipronil) followed by M-7 (acetamiprid) reduced 90.44 per cent aphid population. Both modules were recorded on par with each other in their efficacy. Among eight different IPM modules, M-1 was recorded least effective module in management of aphids on cumin. 
Table 3

Field efficacy of third \& fourth applications of different IPM modules against aphid on cumin in rabi 2018-19. Note: figure in parentheses are arc sign transformed values, given value is the mean of 15 plants from three replications; PTC = Pre treatment count; DAT = days after treatment. In PTC, the difference in aphid population between treatments is due to the impact of first \& second applications of different IPM modules. In column, means followed by common letters are not significantly different at $(\mathrm{P} \leq 0.05)$ by Duncan's Multiple Range test (DMRT).

\begin{tabular}{|c|c|c|c|c|c|c|c|c|c|}
\hline \multirow{3}{*}{$\begin{array}{l}\text { IPM } \\
\text { module }\end{array}$} & \multirow[t]{3}{*}{ PTC } & \multicolumn{4}{|c|}{ Per cent mortality in aphid population } & \multicolumn{4}{|c|}{ Per cent mortality in aphid population } \\
\hline & & \multicolumn{4}{|c|}{ IIIrd Application } & \multicolumn{4}{|c|}{ IVth Application } \\
\hline & & 1 DAT & 3 DAT & 7 DAT & 10 DAT & 1 DAT & 3 DAT & 7 DAT & 10 DAT \\
\hline M-1 & $15.2^{\mathrm{b}}$ & $\begin{array}{l}42.4 \\
(40.61)^{e}\end{array}$ & $\begin{array}{l}56.28 \\
(48.59)^{c}\end{array}$ & $\begin{array}{l}66.33 \\
(54.52)^{c}\end{array}$ & $\begin{array}{l}53.46 \\
(46.96)^{c}\end{array}$ & $\begin{array}{l}58.92 \\
(50.14)^{a b}\end{array}$ & $\begin{array}{l}67.10 \\
(54.99)^{b}\end{array}$ & $\begin{array}{l}77.38 \\
(61.59)^{\mathrm{C}}\end{array}$ & $\begin{array}{l}64.58 \\
(53.47)^{c}\end{array}$ \\
\hline M-2 & $14^{\mathrm{b}}$ & $\begin{array}{l}44.46 \\
(41.8)^{\mathrm{de}}\end{array}$ & $\begin{array}{l}57.17 \\
(49.1)^{c}\end{array}$ & $\begin{array}{l}67.34 \\
(55.14)^{c}\end{array}$ & $\begin{array}{l}54.44 \\
(47.53)^{c}\end{array}$ & $\begin{array}{l}59.08 \\
(50.24)^{a b}\end{array}$ & $\begin{array}{l}67.85 \\
(55.45)^{b}\end{array}$ & $\begin{array}{l}77.41 \\
(61.64)^{c}\end{array}$ & $\begin{array}{l}64.99 \\
(53.71)^{b c}\end{array}$ \\
\hline M-3 & $9.6^{\mathrm{de}}$ & $\begin{array}{l}51.28 \\
(45.72)^{\mathrm{cd}}\end{array}$ & $\begin{array}{l}62.11 \\
(51.99)^{\mathrm{bc}}\end{array}$ & $\begin{array}{l}71.61 \\
(57.79)^{\mathrm{bc}}\end{array}$ & $\begin{array}{l}63.44 \\
(52.78)^{\mathrm{bc}}\end{array}$ & $\begin{array}{l}63.56 \\
(52.86)^{a b}\end{array}$ & $\begin{array}{l}72.00 \\
(58.04)^{a b}\end{array}$ & $\begin{array}{l}86.05 \\
(68.04)^{b}\end{array}$ & $\begin{array}{l}70.22 \\
(56.91)^{b c}\end{array}$ \\
\hline M-4 & $11^{\mathrm{cd}}$ & $\begin{array}{l}53.2 \\
(46.82)^{b c}\end{array}$ & $\begin{array}{l}60.67 \\
(51.15)^{c}\end{array}$ & $\begin{array}{l}69.35 \\
(56.35)^{c}\end{array}$ & $\begin{array}{l}61.54 \\
(51.67)^{c}\end{array}$ & $\begin{array}{l}58.45 \\
(49.86)^{b}\end{array}$ & $\begin{array}{l}69.45 \\
(56.45)^{a b}\end{array}$ & $\begin{array}{l}78.07 \\
(62.07)^{\mathrm{C}}\end{array}$ & $\begin{array}{l}65.86 \\
(54.23)^{b c}\end{array}$ \\
\hline$M-5$ & $5.4^{f}$ & $\begin{array}{l}61.51 \\
(51.64)^{a}\end{array}$ & $\begin{array}{l}70.46 \\
(57.06)^{a}\end{array}$ & $\begin{array}{l}81.80 \\
(64.78)^{a}\end{array}$ & $\begin{array}{l}72.59 \\
(58.43)^{a}\end{array}$ & $\begin{array}{l}66.35 \\
(54.67)^{a}\end{array}$ & $\begin{array}{l}76.25 \\
(60.89)^{a}\end{array}$ & $\begin{array}{l}92.32 \\
(75.29)^{a}\end{array}$ & $\begin{array}{l}81.87 \\
(64.87)^{a}\end{array}$ \\
\hline M-6 & $12.6^{b c}$ & $\begin{array}{l}52.2 \\
(46.3)^{\mathrm{bcd}}\end{array}$ & $\begin{array}{l}63.09 \\
(52.57)^{\mathrm{abc}}\end{array}$ & $\begin{array}{l}70.50 \\
(57.08)^{c}\end{array}$ & $\begin{array}{l}62.19 \\
(52.06)^{C}\end{array}$ & $\begin{array}{l}62.89 \\
(52.46)^{a b}\end{array}$ & $\begin{array}{l}71.53 \\
(57.73)^{a b}\end{array}$ & $\begin{array}{l}85.26 \\
(67.41)^{b c}\end{array}$ & $\begin{array}{l}71.36 \\
(57.63)^{b}\end{array}$ \\
\hline M-7 & $7.4^{\text {ef }}$ & $\begin{array}{l}60.15 \\
(50.9)^{a b}\end{array}$ & $\begin{array}{l}69.43 \\
(56.67)^{\mathrm{ab}}\end{array}$ & $\begin{array}{l}78.91 \\
(63.12)^{a b}\end{array}$ & $\begin{array}{l}71.39 \\
(57.96)^{a b}\end{array}$ & $\begin{array}{l}66.17 \\
(54.47)^{a b}\end{array}$ & $\begin{array}{l}75.24 \\
(60.25)^{a}\end{array}$ & $\begin{array}{l}90.44 \\
(72.78)^{a b}\end{array}$ & $\begin{array}{l}78.19 \\
(62.21)^{a}\end{array}$ \\
\hline M-8 & $21^{a}$ & $\begin{array}{l}0.00 \\
(0.00)^{f}\end{array}$ & $\begin{array}{l}0.00 \\
(0.00)^{d}\end{array}$ & $\begin{array}{l}0.00 \\
(0.00)^{c}\end{array}$ & $\begin{array}{l}0.00 \\
(0.00)^{d}\end{array}$ & $\begin{array}{l}0.00 \\
(0.00)^{c}\end{array}$ & $\begin{array}{l}0.00 \\
(0.00)^{\mathrm{C}}\end{array}$ & $\begin{array}{l}0.00 \\
(0.00)^{d}\end{array}$ & $\begin{array}{l}0.00 \\
(0.00)^{d}\end{array}$ \\
\hline
\end{tabular}

In second year, at 10, 20, 30 and 40 days after germination, the aphid population was recorded significantly lower to control in all IPM modules (P $\leq$ 0.05). 10, 20, 30 and 40 days post germination-first spray, significantly low number of aphids, i.e. 0 to 0.4 aphids per plant, 0 to 0.6 aphids per plant, 0 to 1.4 aphids per plant, and 0 to 4.4 aphids per plant, respectively, were recorded among the treatment of all IPM modules (Table 2). IPM module M-5 (imidacloprid 600 FS as ST) showed zero aphid infestation till 40 days after seed germination and statistically on par to M-7 but significantly differed to rest of the treatments. In second application, IPM module M-5 showed lowest aphids i.e. 0.2 and 1.2 aphids/plant at 50 and 60 days after germination, respectively, and statistically on par to M-7 (0.4 and 1.6 aphids/plant) proved most effective. However, aphid infestation in control plots steadily increased from 0.6 aphids/plant at 10 days after germination to 14 aphids/branch at 60 days after germination (Table 2). One day before treatment of third application, per plant aphid populations were ranged from 6.0 to 18.2 in all modules, showed significant difference in population due to treatment effect of first and second applications. Mortality in aphid population at 1, 3, 7, and 10 days after application showed that all IPM modules were significantly better in reduction of aphid population to control, whereas highest reduction percentage recorded at 7 days after treatment (Table 4). IPM module M-5 recorded highest mortality $80.87 \%$ followed by M-7 (79.63\%) and both were statistically on par in their efficacy. Module M-4 reduced lowest population 
(66.18\%) followed by M-2 and M-3 but statistically at par. In fourth application, all IPM modules consistently showed higher per cent reduction in aphid population than the control and IPM modules M-5 at 1, 3, and 7 days after treatment, reduced 79.97, 86.92 and 93.91 per cent aphid population, respectively and which was on par to M-7 at all intervals (Table 4). Other IPM modules were recorded as middle order of effectiveness in management of aphids in cumin crop.

Table 4

Field efficacy of third \& fourth applications of different IPM modules against aphid on cumin in rabi 2019-20; Note: figure in parenthesis are arc sign transformed values; given value is the mean of 15 plants from three replications; PTC = Pre treatment count; DAT = days after treatment, values in parentheses are angular transformed values; In PTC, the difference in aphid population between treatments is due to the impact of first \& second applications of different IPM modules. In column, means followed by common letters are not significantly different at $(P \leq 0.05)$ by Duncan's Multiple Range test (DMRT).

\begin{tabular}{|c|c|c|c|c|c|c|c|c|c|}
\hline \multirow{3}{*}{$\begin{array}{l}\text { IPM } \\
\text { module }\end{array}$} & \multirow[t]{3}{*}{ PTC } & \multicolumn{4}{|c|}{ Per cent mortality in aphid population } & \multicolumn{4}{|c|}{ Per cent mortality in aphid population } \\
\hline & & \multicolumn{4}{|c|}{ IIIrd Application } & \multicolumn{4}{|c|}{ IVth Application } \\
\hline & & 1 DAT & 3 DAT & 7 DAT & 10 DAT & 1 DAT & 3 DAT & 7 DAT & 10 DAT \\
\hline \multirow[t]{2}{*}{ M-1 } & $13.2^{b}$ & 56.67 & 59.46 & 67.71 & 56.62 & 53.84 & 68.25 & 77.76 & 72.13 \\
\hline & & $(48.82)^{b}$ & $(50.45)^{d}$ & $(55.36)^{\mathrm{bc}}$ & $(48.78)^{c}$ & $(47.19)^{c}$ & $(55.68)^{c}$ & $(61.89)^{d}$ & $(58.13)^{\mathrm{b}}$ \\
\hline \multirow[t]{2}{*}{ M-2 } & $13^{\mathrm{b}}$ & 62.14 & 63.04 & 67.17 & 55.23 & 54.69 & 67.15 & 78.38 & 73.35 \\
\hline & & $(52.01)^{\mathrm{ab}}$ & $(52.54)^{\mathrm{cd}}$ & $(55.02)^{\mathrm{bc}}$ & $(47.98)^{\mathrm{c}}$ & $(47.68)^{c}$ & $(55.02)^{c}$ & $(62.29)^{\mathrm{cd}}$ & $(58.91)^{\mathrm{b}}$ \\
\hline \multirow[t]{2}{*}{ M-3 } & $11.6^{c}$ & 63.51 & 67.71 & 75.06 & 69.28 & 67.38 & 70.68 & 86.18 & 74.49 \\
\hline & & $(52.82)^{\mathrm{ab}}$ & $(55.38)^{\mathrm{abc}}$ & $(60.04)^{a}$ & $(56.32)^{a b}$ & $(55.16)^{b}$ & $(57.25)^{c}$ & $(68.16)^{b}$ & $(59.66)^{b}$ \\
\hline \multirow[t]{2}{*}{$M-4$} & $10.4^{c}$ & 62.65 & 65.28 & 66.18 & 54.46 & 62.98 & 69.01 & 79.46 & 70.09 \\
\hline & & $(52.33)^{\mathrm{ab}}$ & $(53.88)^{b c d}$ & $(54.43)^{\mathrm{c}}$ & $(47.54)^{c}$ & $(52.5)^{\mathrm{b}}$ & $(56.17)^{c}$ & $(63.03)^{\mathrm{cd}}$ & $(56.83)^{b}$ \\
\hline \multirow[t]{2}{*}{$M-5$} & $6^{e}$ & 68.50 & 71.85 & 80.87 & 74.29 & 79.97 & 86.92 & 93.31 & 84.86 \\
\hline & & $(55.84)^{a}$ & $(57.97)^{a}$ & $(64.1)^{\mathrm{a}}$ & $(59.51)^{a}$ & $(63.45)^{a}$ & $(68.86)^{a}$ & $(75.15)^{a}$ & $(67.16)^{a}$ \\
\hline \multirow[t]{2}{*}{ M-6 } & $9^{d}$ & 65.19 & 66.06 & 74.52 & 68.26 & 76.30 & 81.69 & 84.87 & 73.73 \\
\hline & & $(53.84)^{a}$ & $(54.35)^{b c}$ & $(59.68)^{a b}$ & $(55.74)^{b}$ & $(60.87)^{a}$ & $(64.72)^{b}$ & $(67.13)^{b c}$ & $(59.17)^{b}$ \\
\hline \multirow[t]{2}{*}{ M-7 } & $8.2^{d}$ & 66.38 & 70.06 & 79.63 & 74.08 & 77.51 & 83.93 & 91.71 & 82.49 \\
\hline & & $(54.61)^{a}$ & $(56.84)^{a b}$ & $(63.51)^{a}$ & $(59.41)^{a}$ & $(61.87)^{a}$ & $(66.63)^{a b}$ & $(73.93)^{a}$ & $(65.62)^{a}$ \\
\hline \multirow[t]{2}{*}{ M-8 } & $18.2^{\mathrm{a}}$ & 0.00 & 0.00 & 0.00 & 0.00 & 0.00 & 0.00 & 0.00 & 0.00 \\
\hline & & $(0.0)^{c}$ & $(0.0)^{\mathrm{e}}$ & $(0.0)^{d}$ & $(0.0)^{d}$ & $(0.0)^{d}$ & $(0.0)^{d}$ & $(0.0)^{\mathrm{e}}$ & $(0.0)^{c}$ \\
\hline
\end{tabular}

\section{Yield and Quality.}

In first year experiment, the highest seed yield of cumin $892 \mathrm{~kg}$ per hectare was recorded in the plots treated with IPM module M-5, which was significantly superior over rest of the IPM modules tested against aphid. The next most effective IPM modules were M-7, M-3, and M-6 which recorded seed yield of 756, 751 and $723 \mathrm{~kg}$ per hectare, respectively. The untreated control recorded the lowest $341 \mathrm{~kg}$ per hectare seed yield (Figure 1). In second year, the highest seed yield of 976 
kg per hectare was recorded with IPM module M-5, which was statistically similar to M-7 (857 kg per ha). The next most efficient IPM modules were M-3, M-6, and M-4 with non-significant difference. The control showed a reduction of $643 \mathrm{~kg}$ per ha seed yield in comparison with the best IPM module M-5 (Figure 2). Based on two years study pooled data, IPM module M-5 was rated as utmost effective module followed by IPM modules M-7, M-3 and M-6. IPM module M- 1 was the least effective module to manage aphids mixed population. Similarly, in term quality, the highest essential oil content (5.98\%) in cumin seeds and test weight per 1000 seeds $(5.24 \mathrm{~g})$ were recorded from cumin seeds harvested under IPM module M-5.

\section{Field validation.}

In the field trials conducted for two years at farmer's field, the average seed yield $1072.5 \mathrm{~kg}$ per hectare of cumin variety GC-4 was recorded in the treatment of IPM module M-5, whereas, $885 \mathrm{~kg}$ per hectare seed yield of cumin variety GC-4 was obtained in the same piece of land under farmer's pest management practices. IPM module M-5 enhanced the average cumin yield by $187.5 \mathrm{~kg}$ per hectare (21.19\%) for the value of Rs. 30,000 per hectare over farmer's pest management practices, validated its effectiveness by the farmers.

\section{Economics.}

The highest gross return (Rs. 149440) and net return (Rs. 108990) was recorded in cumin crop treated with IPM module M5 followed by IPM module M-7 (gross return Rs. 128960; net return Rs. 79150) and M-3 (gross return Rs. 117280; net return Rs. 69030) (Table 5). These IPM modules were found more effective in controlling aphids in cumin over rest of the IPM modules tested. The highest B: C ratio 1: 3.69 was also obtained in $M-5$ than $M-7$ and $M-3$ (1: 2.97 and 1: 2.43). Lowest gross return (Rs. 82720), net return (Rs.34340) and B: C ratio 1: 1.71 was recorded with IPM module M-1, proved least effective module in management of aphids on cumin.

Table 5

Cost economics of IPM modules against aphid of cumin; Note: Yield-two years pooled, Gross return = Yield $\mathrm{x}$ Market price of cumin seed (Rs. 160 per kg); Net Returns = Gross Return - Total Cost; B:C ratio = Gross Returns $/$ Total Cost .

\begin{tabular}{|c|c|c|c|c|c|c|}
\hline \multirow[t]{2}{*}{$\begin{array}{l}\text { IPM } \\
\text { Module }\end{array}$} & $\begin{array}{l}\text { Seed yield } \\
\text { (kg/ha) }\end{array}$ & $\begin{array}{l}\text { Cost of plant } \\
\text { protection }\end{array}$ & $\begin{array}{l}\text { Total cost of } \\
\text { production (Rs/ha) }\end{array}$ & $\begin{array}{l}\text { Gross returns } \\
\text { (Rs/ha) }\end{array}$ & $\begin{array}{l}\text { Net returns } \\
\text { (Rs/ha) }\end{array}$ & $\begin{array}{l}\text { B:C } \\
\text { Ratio }\end{array}$ \\
\hline & \multicolumn{6}{|l|}{ Pooled } \\
\hline M-1 & 517 & 11380 & 48380 & 82720 & 34340 & 1.71 \\
\hline$M-2$ & 530 & 20450 & 57450 & 84800 & 27350 & 1.48 \\
\hline M-3 & 733 & 11250 & 48250 & 117280 & 69030 & 2.43 \\
\hline$M-4$ & 562 & 6830 & 43830 & 89920 & 46090 & 2.05 \\
\hline M-5 & 934 & 3450 & 40450 & 149440 & 108990 & 3.69 \\
\hline M-6 & 671 & 6730 & 43730 & 107360 & 63630 & 2.46 \\
\hline$M-7$ & 806 & 6410 & 43410 & 128960 & 79150 & 2.97 \\
\hline M-8 & 337 & 0 & 37000 & 53920 & 16920 & 1.46 \\
\hline
\end{tabular}

\section{Discussion}




\section{Field efficacy studies.}

Aphid species Myzus persicae (Sulzer) and Aphis gossypii Glover were recorded in all the plots of three replications for two consecutive years. Its infestation initiated at 20 days after seed germination with very low in number and became abundant from second week of January till end of the February confirming that both the species are the important pest of cumin in semi-arid region of the country. Meena et al. ${ }^{1}$ reported that aphid infestation occurred on cumin at three to four leaf stages, almost 30 days after germination and being active throughout the cropping season. Four different treatments integrated in the form of IPM module were applied as seed and soil treatment and 3 foliar sprays with botanicals, biopesticides and chemical insecticides in a specified interval, sustainably managed the aphid's mixed population in the field, and also conferred the relative safety to predators and parasitoids and minimized the risk of pesticide residue in the produce. The data for initial 2 treatment applications showed that up to 50 and 60 days after germination in both years, aphid population densities were significantly lower among all IPM modules, compared with the control. However, in IPM module M-5 and M-7, seed treatment with imidacloprid 600 FS and thiamethoxam 25 WG, respectively escaped the crop from aphid infestation up to 40 days after germination in both the years. Seed treatment with imidacloprid 600 FS @ 5 ml/ $\mathrm{kg}$ seed in blackgram was found effective against whitefly ${ }^{47}$, and leafhopper, thrips and whitefly on cowpea with highest gross and net returns ${ }^{48}$. Sujatha and Bharpoda ${ }^{49}$ reported that seed treatment of moongbean with thiamethoxam $25 \mathrm{WG}$ $(0.01 \%)$ was found to be more effective against the sucking pests by recording lowest population of aphids and whiteflies are evident to the present finding. Soil application of castor cake and neem cake before seed sowing played a role in healthy growth of cumin crop's in initial growth stage and also to keep aphid population under check. In second application, treatments ker plant extract (10 ml/lit), azadirachtin $0.03 \mathrm{EC}(5 \mathrm{ml} / \mathrm{lit})$ and azadirachtin $0.03 \mathrm{EC}(3 \mathrm{ml} / \mathrm{lit})$ applied under IPM module M-5, M-7 and M-3, respectively at 45 days after germination also recorded lower aphid population ( 0.4 to 2.4 aphids/branch in first year and 1.2 to 2.0 aphids/branch in second year) till 60 days after germination than remaining modules and untreated control (11.4 and 14.0 aphids/branch in both the years). Meena et al. ${ }^{50}$ screened out the ker plant extract $(10 \mathrm{ml} /$ lit.) as foliar spray, reduced $68.96 \%$ aphid population on coriander under field conditions. Ker, Capparis decidua Edgew (Forssk.) plant contains insecticidal compounds (capparisinine, triacontanol and tetrahydropyran-2-one) shown enormous insecticidal activity against a wide range of insect pests ${ }^{51,52}$. Other treatments release of coccinellids larvae and yellow sticky traps applied in IPM module M-6, M-4 and M-1 also played role in management of aphids up to 60 days after germination. Even then aphid population gradually raised with increase of crop foliage and environmental factors favourable for aphid multiplication, therefore, third and fourth applications of IPM modules were applied at 70 and 85 days after germination to control aphids. The data for two year study showed that at 7 days after treatment for 2 sprays, per cent reduction in aphid population was recorded highest among IPM modules compared with the control. IPM modules M-5 (third and fourth application with Verticillium lecanii $1 \times 10^{8} \mathrm{cfu} / \mathrm{g}$ and fipronil $5 \%$ SC) proved most effective (92.32 and $93.31 \%$ reduction at 7 DAT in both the years) module in management of aphids on cumin. Javed et al. ${ }^{53}$ screened the pathogenicity of fungal strain Verticillium lecanii (CS-625), found $95 \%$ mortality of aphid, Myzus persicae Sulzer after 10 days of treatment when applied as filtrate. Fipronil @ 2ml/I was also found effective in reduction of whitefly population ${ }^{54}$. The next effective IPM modules were $\mathrm{M}-7$ and $\mathrm{M}-3$, found significantly superior over rest of the IPM modules and important as it reduced $90.44,91.71 \%$ and $86.05,86.18 \%$ aphid population in both the years and comparatively safer to natural enemies of aphid due to use of fungal product Metarhizium anisopliae and a botanical tumba (Citrullus colosynthis) fruit extract as its third component. Cucurbitacin E glycoside content of $C$. colosynthis shows insecticidal effect on aphids ${ }^{42}$. Fresh fruit extract of tumba (C. colosynthis) @ 10ml/litre, found effective in management of aphid in coriander ${ }^{50}$ and thrips in fennel under integrated organic farming system ${ }^{55}$ are accordance with the present findings.

Treatments of IPM modules resulted in lower aphid infestation and higher crop yields for both the years. One critical factor in cumin protection from aphid infestation was excellent mode of treatments application (chemical insecticide than botanicals, biopesticides and again chemical insecticide) in the form of IPM modules right from seed treatment at the time 
of seed sowing to foliar spray at 70 and 85 days after germination. During two year's crop production seasons, 4 applications only provided enough protection for aphid's mixed population, and subsequently resulted in higher yields compared with untreated control. The economics data of two years study found that IPM module M-5 recorded higher gross and net return with highest benefit cost ratio than other modules due to effective control of aphids, per unit area higher seed yield and low input cost of treatments, however, IPM module M-7 and M-6 are statistically close to M-5. It also proved the effectiveness of $M-5$ and other next effective modules against aphid on cumin. In field validation, IPM module M-5 appreciated cumin seed yield $187.5 \mathrm{~kg}$ per ha over farmer's aphid management practices, earned Rs. 30,000 per ha additional income confirmed the research finding by the farmers. No research work was carried out earlier by the researchers in this aspect particularly on cumin in India and abroad, hence, results could not be compared and discussed. However, few studies are quoted on other crops to support the present study.

The evaluated IPM modules were comparatively safer to predators and parasitoids, however, we are unaware about up to what extent, these IPM module minimized the pesticide residue in cumin seed, need to be analysed under accredited residue analysis laboratory in further study. Pesticide residue is the key parameter of International Standards for export as cumin is also an export oriented key crop of India among seed spices.

\section{Conclusion}

It is concluded from the study that the IPM module M-5 consisted by seed treatment with imidacloprid 600FS @ 3ml $/ \mathrm{kg}$ seed followed by foliar applications of ker (Capparis decidua) plant extract @ 10ml/lit + Verticillium lecanii (1x10 $\left.{ }^{8} \mathrm{cfu} / \mathrm{g}\right) @$ 6g/lit. + fipronil 5\%SC @ 0.035\% at 45, 70 and 85 days after germination, respectively reduced aphid population build up significantly on cumin in semi-arid region of India. The IPM module M-5 was also recorded significantly superior for maximum seed yield (934 kg/ha two years average), seed quality (5.98\% essential oil and $5.24 \mathrm{~g}$ test weight), net return (Rs. 108990) and B: C ratio (3.69) and was being comparatively safer to natural enemies (predators and parasitoids) and also minimize the development of pest resistance to insecticides under field conditions.

\section{Declarations}

\section{Acknowledgement}

The authors are grateful to the Director, ICAR-National Research Centre on Seed Spices, Ajmer (Rajasthan), India for providing support and facilities to carried out the research at institute's research fam. The Entomopathogens provided by the ICAR-NBAIR, Bengaluru is greatly acknowledged. We also thank Dr. K. Kant, Pr. Scientist, Sh. S.R. Meena, ACTO for their support in experimentation \& Dr. Balraj Singh, former Director of the institute for his comments on the draft of this manuscript.

\section{Funding}

This study was funded by the Indian Council of Agricultural Research, New Delhi-110012, India

\section{Author contributions}

N.K.M., R.S., M.M and R.D.M. conducted the experiment; A.K.V., R.S.M., and R.Y. supported in data collection and analysis; N.K.M., S.C. wrote the manuscript. All authors reviewed the manuscript.

\section{Competing interests}


The authors declare no competing interests.

Correspondence and requests for materials should be addressed to N.K.M.

\section{References}

1. Meena, N. K., Lal, G., Kant, K., Meena, R. S. \& Meena, S. R. Pest scenario of cumin (Cuminum cyminum L.) and population dynamics in semi-arid region of Rajasthan. International J. Seed Spices 8, 80-83 (2018).

2. Kant, K., Sharma, Y. K., Meena, S. S., Mehta, R. S. \& Meena, S. R. Saving seed spices from insect enemies. Indian Hort. 55, 25-27 (2010).

3. Afonin, A. N., Greene, S. L., Dzyubenko, N. I., Frolov, A. N. Interactive agricultural ecological atlas of Russia and neighbouring countries. Economic plants and their diseases, pests and weeds. http://www.agroatlas.ru. (2008).

4. Blackman, R. L. \& Eastop, V. F. Aphids on the world's crops: Identification and information guide. John Wiley and Sons Ltd, Chichester, UK, p. 375 (2000).

5. Carletto, J., Lombaert, E., Chavigny, P., Brevault, T., Lapchin, L. \& Masutti, F. V. Ecological specialization of the aphid, Aphis gossypii Glover on cultivated host plants. Molecular Ecology 18, 2198-2212 (2009).

6. Ahman, I., Kim, S. Y. \& Zhu, L. H. Plant genes benefitting aphids potential for exploitation in resistance breeding. Front. Plant Sci. 10, 1452 (2019).

7. Abang, A. F., Srinivasan, R., Kekeunou, S., Hanna, R., Kamga, R. \& Bilong, C.F.B. Influence of okra (Abelmoschus spp.) accessions on colonization by Aphis gossypii (Hemiptera: Aphididae) and their effects on aphid biological parameters. Florida Entomologist 101, 549-558 (2018).

8. Meena, N. K. \& Kumar, A. Field evaluation of alphacypermethrin (10\%SC) against insect pests of okra and their phytotoxic effect on plants. Indian Journal of Applied Entomology. 25, 139-143 (2011).

9. Liu, X. D., Zhai, B. P., Zhang, X. X. \& Zong, J. M. Impact of transgenic cotton plants on a non-target pest, Aphis gossypii Glover. Ecol. Entomol. 30, 307-315 (2005).

10. Mota, T. A., de Souza, M. F., Fernandes, M. G., da Fonseca, P. R. B., Kassab, S.O. \& de Quadros, J. C. Biological parameters of the non-target pest Aphis gossypii Glover (Hemiptera: Aphididae) on genetically modified (GM Bt cotton. African Journal of Biotechnology 12, 1987-1992 (2013).

11. Anonymous. Spices: area, production and productivity in India. Directorate of Arecanut and Spices Development (GOI), Calicut, Kerala (2021a). https://www.dasd.gov.in/index.php/content/index/statistics

12. Anonymous. Spices Board, Ministry of Commerce and Industry, Govt. of India, Kochi, Kerala (2021b). http://www.indianspices.com/sites/default/files/majorspicewise2021.

13. lacobellis, N. S., Cantore, P.L., Capasso, F. \& Senatore, F. Antibacterial activity of Cuminum cyminum L. and Carum carvi L. essential oils. J. Agric. Food Chem. 53, 57-61 (2005).

14. El-Kani, M., Fereshteh, G., Mehdi, M. \& Soosan, R. Extraction of volatile oil from cumin (Cuminum cyminum L.) with superheated water. J. food Process Eng. 30, 255-266 (2007).

15. De, M. L., De, F. V., Fratianni, F. \& Nazzaro, F. Chemistry, antioxidant, antibacterial and antifungal activities of volatile oils and their components. Nat. Prod. Commu. 4, 1741-50 (2009).

16. Lee, H. S. Cuminaldehyde: Aldose reductase and alpha glucosidase inhibitor derived from Cuminum cyminum L. seeds. J. Agric. Food Chem. 53, 2446-53 (2005).

17. Al-Hashemi, F. H. Y. Chromatographic separation and identification of some volatile oils, organic acids and phenols from the seeds of Cuminum cyminum growing in Iraq. Int. J. Recent Res. Adv. Studies 19, 80-90 (2014).

18. Tahraoui, A., El- Hilay, J., Israili, Z. H. \& Lyoussi, B. Ethnopharmacological survey of plants used in the traditional treatment of hypertension and diabetes in southeastern Morocco (Errachidia province). J Ethnopharmacol. 110, 105- 
17 (2007).

19. Nalini, N., Sabitha, K., Vishwanathan, P. \& Menon, V.P. Influence of spices on the bacterial (enzyme) activity in experimental colon cancer. J. Ethnopharmacol. 62, 15-24 (1998).

20. Malhotra, S. K. \& Vashishtha, B. B. Package of practices for production of seed spices. Book Publisher Director, National Research Centre on Seed Spices, Ajmer, pp 3-19 (2008).

21. Verma, A. K., Singh, R., Choudhary, S. \& Lal, G. Cultivation of dollar earning cumin crop for higher income. Acta Scientific Agriculture 2, 46-48 (2018).

22. Dangi, N.L., Mahla, M.K., Ahir, K.C. \& Swami, H. Bio-efficacy of different insecticides against aphid (Myzus persicae) in cumin (Cuminum cyminum L.), Journal of Spices and Aromatic Crops, 26, 83-85 (2016).

23. Yadav, T., Acharya, V. S., Yadav, A. \& Yadav, R. Biology of aphid, Myzus persicae (Sulzer) on cumin (Cuminum cyminum Linn.) under laboratory conditions. Int. J Chem. Studies 7, 1992-1994 (2019).

24. Singh, G. \& Grewal, G. S. Biology of Myzus persicae (Sulz.) on rocket salad (Eruca sativa Linn.) in Punjab. J Res. Punjab Agril. Univ 24, 628-637 (1987).

25. Gupta, B. M. \& Yadava, C. P. S. Seasonal incidence of aphid Myzus persicae (Sulzer) on cumin in semi arid Rajasthan. Indian Journal of Entomology, 52, 465-469 (1990).

26. Italiya, L. M. \& Sisodiya, D. B. Population dynamics of aphid, Myzus persicae (Sulzer) (Homoptera: Aphididae) on cumin. Trends in Biosciences 10, 5693-5694 (2017). http://trendsinbiosciencesjournal.com/20193337910

27. Bass, C., Puinean, A.M., Zimmer, C.T., Denholm, I., Field, L.M., Foster, S.P., Gutbrod, O., Nauen, R., Slater, R. \& Williamson, M.S. The evolution of insecticide resistance in the peach potato aphid, Myzus persicae. Insect Biochem. Mol. Biol., 51, 41-51 (2014). doi: 10.1016/j.ibmb.2014.05.003.

28. Tang, Q.L., Ma, K.S., Hou, Y.M. \& Gao, X.W. Monitoring insecticide resistance and diagnostics of resistance mechanisms in the green peach aphid, Myzus persicae (Sulzer) (Hemiptera: Aphididae) in China, Pestic Biochem Physiol. 143:39-47 (2017).

29. Wang, K. Y., Guo, Q. L., Xia, X. M., Wang, H. Y., \& Lu, T. X. Resistance of Aphis gossypii (Homoptera: Aphididae) to selected insecticides on cotton from five cotton production regions in Shandong, China. Journal of Pesticide Science, 32, 372-378 (2007). doi:10.1584/jpestics.G06-51.

30. Huseth, A.S., Chappell, T.M., Chitturi, A., Jacobson, A.L. \& Kennedy, G.G. Insecticide resistance signals negative consequences of widespread neonicotinoid use on multiple field crops in the U.S. cotton belt. Environ. Sci. Technol., 52, 2314-2322 (2018).

31. Wilson, L.J., Bauer, L.R. \& Lally, D.A. Effect of early season insecticide use on predators and outbreaks of spider mites (Acari: Tetranychidae) in cotton. Bulletin of Entomological Research. 88, 477-488 (1998). doi: $10.1017 /$ S000748530004222X.

32. El-Wakeil, N., Gaafar, N., Sallam, A. \& Volkmar, C. Side effects of insecticides on natural enemies and possibility of their integration in plant protection strategies. In book Insecticides-Development of Safer and More Effective Technologies (2013), http://dx.doi.org/10.5772/54199

33. Overton, K., Hoffmann, A.A., Reynolds, O.L. \& Umina, P. A. Toxicity of insecticides and miticides to natural enemies in Australian grains: A review, Insects 12, 187 (2021). https://doi.org/10.3390/insects12020187.

34. Meena, N. K., Lal, G., Meena, S. S., Kant, K. \& Meena, R. D. Screening of coriander varieties/entries for their relative susceptibility against aphids under field conditions. J. Hortl. Sci 14, 39-43 (2019).

35. Upadhyay, R.K., Yadav, N. \& Ahmad, S. Insecticidal potential of Capparis deciduas on biochemical and enzymatic parameters of Tribolium castaneum (Herbst). Acta Universitatis Sapientiae Agriculture and Environment 3, 4567(2011). 
36. Nazar, S., Hussain, M.A., Khan, A., Muhammad, G. \& Tahir, M.N. Capparis decidua Edgew (Forssk.): A comprehensive review of its traditional uses, phytochemistry, pharmacology and nutrapharmaceutical potential. Arabian Journal of Chemistry 13, 1901-1916 (2020).

37. Meena, N.K., Lal, G., Kant, K. \& Khan, M.A. Products (non botanical extracts) developed. Seed Spices E-News Letter, ICAR-NRCSS, September-October 11 (5), (2018).

38. Adam, S., Al-Yahya, M. \& Al-Farhan, A. Response of Najdi sheep to oral administration of Citrullus colocynthis fruits. Small Rumin. Res., 40: 239-244 (2001).

39. Hatam, N.A., Whiting, D.A. \& Yousif, N.J. Cucurbitacin glycosides from Citrullus colocynthis. Phytochemistry, 28 : 1268-1271 (1989).

40. Seger, C., Sturm, S., Mair, M., Ellmerer, E. \& Stuppner, H. H and C NMR signal assignment of cucurbitacin derivatives from Citrullus colocynthis (L.) Schrader and Ecballium elaterium (L.) (Cucurbitaceae). Magn. Reson. Chem., 43(6): 489-91(2005).

41. Abbas, D., Simon, G., Ali, R., Hossein, N., Masoud, M., Lutfun, N. \& Satyajtt, D. Flavone C-glycoside and cucurbitacin glycoside from Citrullus colocynthis. DARU Journal of Pharmaceutical Sciences, 14(3): 109-114 (2006).

42. Torkey, H.M., Abou-Yousef, H.M., Abdel Azeiz, A.Z. \& Hoda, E.A.F. Insecticidal effect of cucurbitacin E-glycoside isolated from Citrullus colocynthis against Aphis craccivora. Australian Journal of Basic and Applied Sciences 3, 4060-4066 (2009).

43. Ahmed, M., Peiwen, Q., Gu, Z., Liu, Y., Sikandar, A., Hussain, D., Javeed, A., Shafi, J., Iqbal, M.F., An, R., Guo, H., Du, Y., Wang, W., Zhang, Y.1 \& Ji, M. Insecticidal activity and biochemical composition of Citrullus colocynthis, Cannabis indica and Artemisia argyi extracts against cabbage aphid (Brevicoryne brassicae L.). Scientific Reports 10:522 (2020). https://doi.org/10.1038/s41598-019-57092-5.

44. Gupta, H.C.L. Natural occurring insecticides, In book Insecticides: Toxicology and Uses, Agrotech Publishing Academy, Udaipur, Rajasthan 22-35 (1999).

45. Kapas, A., Andras, C. D., Dobre, T. G., Vass, E., Szekely, G., Stroescu, M., Lanyi, S. \& Abraham, B. The kinetic of essential oil separation from fennel by microwave assisted hydro-distillation (MWHD). UPB Scientific Bulletin, Series B, 73, 113120 (2011).

46. Abott, W.S. A method of computing the effectiveness of insecticides. J. econ. Ent. 18, 265-267 (1925).

47. Men, U.B., Thakare, A.Y. \& Deshmukh, S.D. Management of Bemisia tabaci Genn. and Scirtothrips dorsalis Hood on rabi summer sunflower with herbals and chemicals. Crop Protection and Production 1, 148 (2005).

48. Anusha, C. H., Balikai, R. A. \& Patil, R.H. Insect pest of cowpea and their management- A review. Journal of Experimental Zoology India 19, 635-642 (2016).

49. Sujatha, B. \& Bharpoda, T.M. Evaluation of insecticides against sucking pests in greengram grown during kharif. Int $J$ Curr Microbiol Appl Sci. 6, 1258-1268 (2017).

50. Meena, N. K., Singh, B., Lal, G., Kant, K. \& Meena, R.D. Sustainable management of aphid in coriander (Coriandrum sativum L.) through botanicals and bio-pesticides. International J. Seed Spices 6, 25-31 (2016).

51. Upadhyay, R. K. Insecticidal properties of kareel plant (Capparis decidua: Capparidaceae) a desert shrub: A review. World Journal of Zoology 8, 75-93 (2012).

52. Upadhyay, R. K. Kareel plant: A natural source of medicines and nutrients. International Journal of Green Pharmacy 5, 255-265 (2013).

53. Javed, K., Javed, H., Mukhtar, T. \& Qiu, D. Pathogenicity of some entomopathogenic fungal strains to green peach aphid, Myzus persicae Sulzer (Homoptera: Aphididae). Egypt J Biol Pest Control 29, 1-7 (2019).

54. Meena, L. K. \& Raju, S. V. S. Bioefficacy of insecticides against whitefly and leafhoppers of tomato under field conditions. Annals Plant Prot. Sci. 22, 14-17 (2014). 
55. Meena, N.K., Lal, G., Meena, R.D. and Choudhary, M.K. 2019. Field evaluation of IPM modules for thrips management in fennel under integrated organic farming system. International J. Seed Spices 9(1):85-90

\section{Figures}

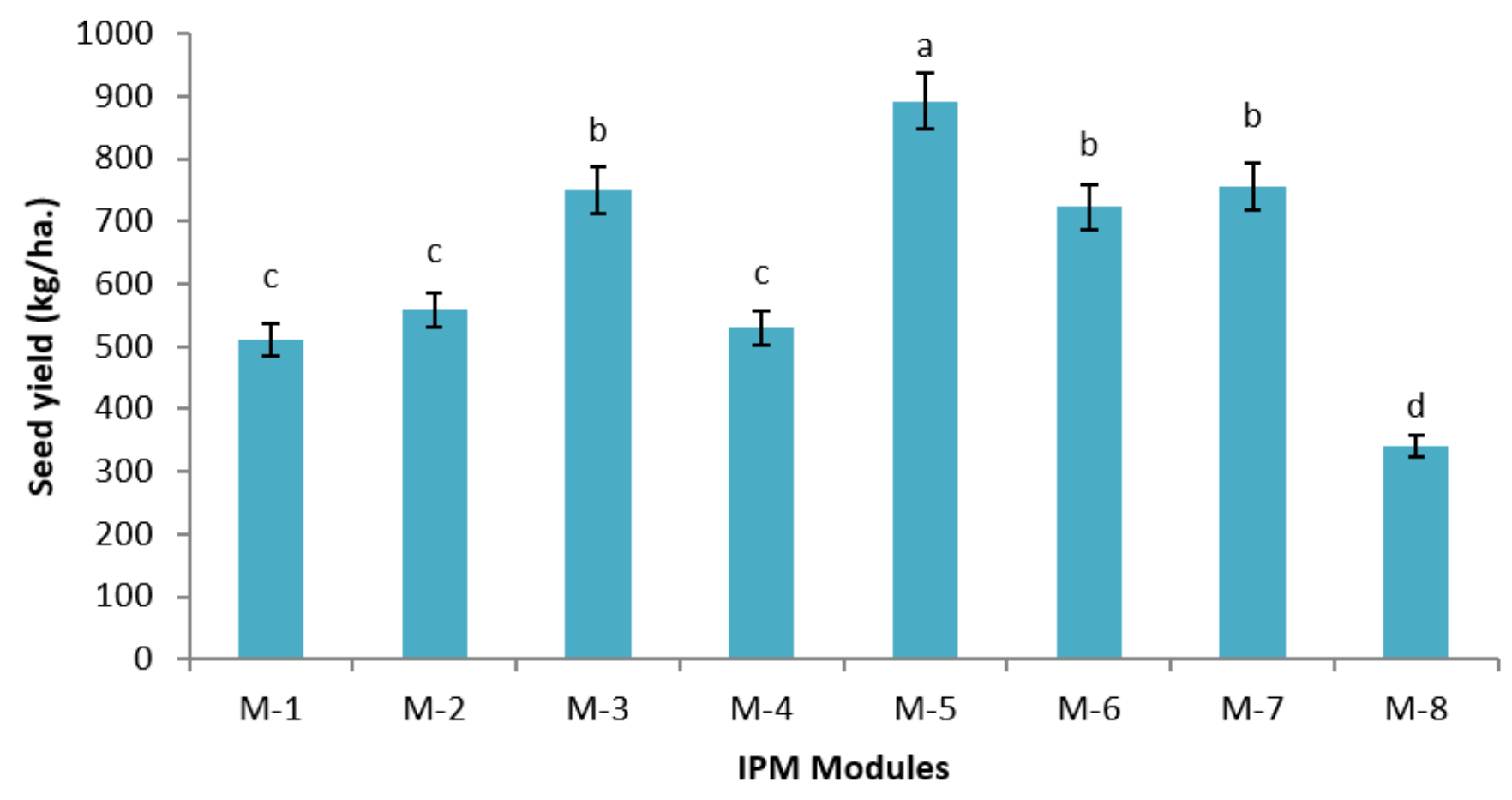

Figure 1

Cumin seed yield in field efficacy treatments during rabi 2018-19 


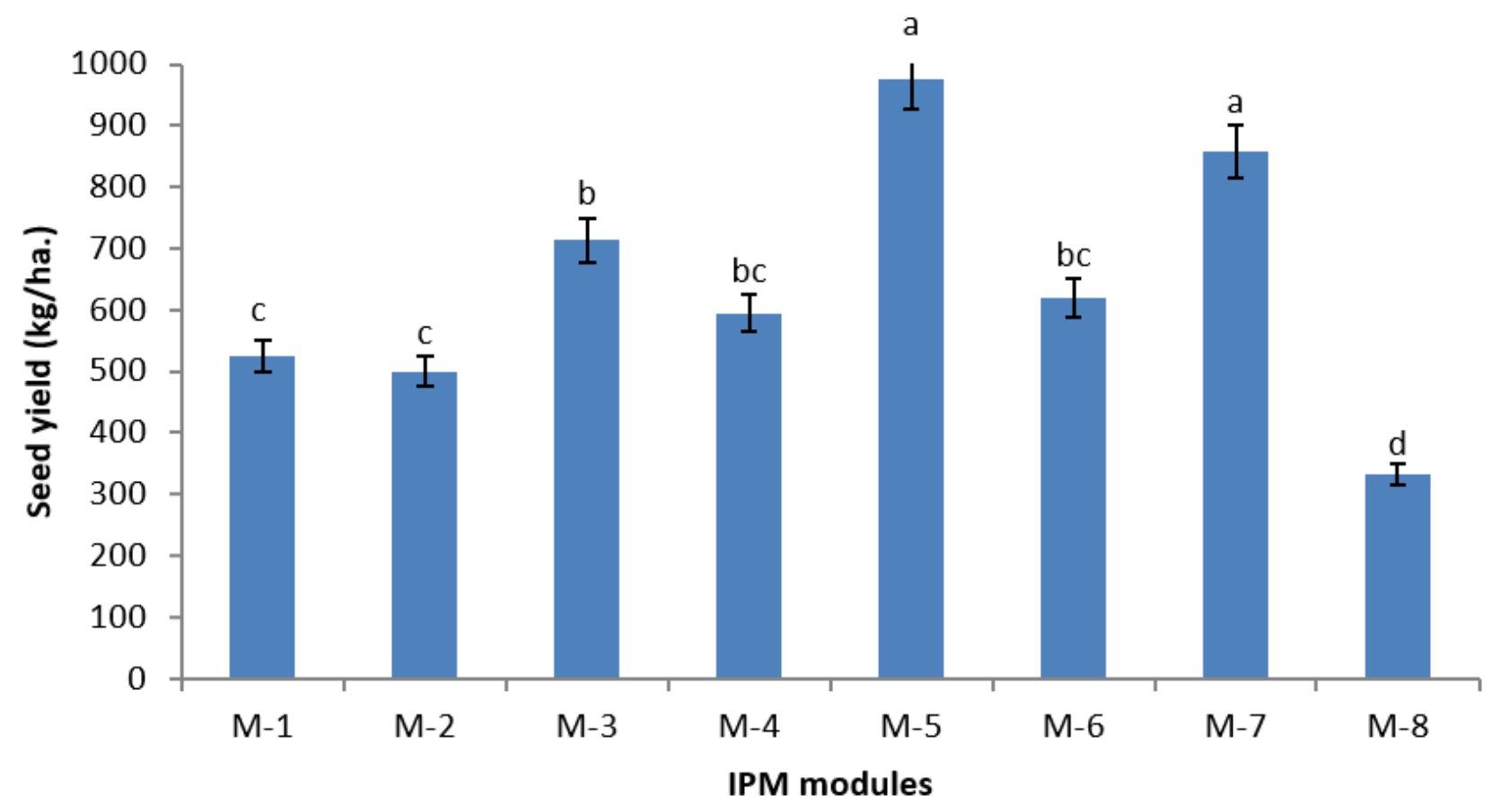

Figure 2

Cumin seed yield in field efficacy treatments during rabi 2019-20 